\title{
The Relationship between EFL Teachers' Motivation and Job Satisfaction in Mashhad Language Institutions
}

\author{
Najmeh Noori*, Mohammad Ali Fatemi, Hossein Najjari \\ Department of English, Torbat-e-Heydareih Branch, Islamic Azad University, Torbat-e-Heydareih, Iran \\ Email: ${ }^{*}$ nj_noori@mail2student.com
}

Received 4 August 2014; revised 20 September 2014; accepted 22 October 2014

Copyright (C) 2014 by authors and OALib.

This work is licensed under the Creative Commons Attribution International License (CC BY).

http://creativecommons.org/licenses/by/4.0/

(c) (i) Open Access

\begin{abstract}
The scarcity of research on EFL teachers' job satisfaction and motivation prompted this study which aimed at identifying the relationship between EFL teachers' motivation and job satisfaction. To achieve this goal, the researcher selected 250 EFL teachers randomly with different years of experience in Mashhad language institutions. To collect the required data, the researcher employed Teacher's Motivation Questionnaire (TMQ) to elicit sources of motivation of EFL teachers and Teachers' Job Satisfaction Questionnaire (TJSQ) to elicit the job satisfaction levels. The results revealed a significant positive relationship $(r=0.44, p<0.01)$ between EFL teachers' motivation and job satisfaction in Mashhad language institutions.
\end{abstract}

\section{Keywords}

Teachers' Motivation, Teacher Job Satisfaction, EFL Teachers, Mashhad Language Institutions

Subject Areas: Education, Linguistics, Psychology, Sociology

\section{Introduction}

In the process of development of any educational system around the world, job satisfaction is vital. Special training, a high level of education, focus competencies, educational resources, and strategies determine whether or how educational success and performance happen [1]. As [2], "there is a growing body of evidence that when teachers feel good about their work, pupil achievement improves" (p. 73). Job satisfaction not only affects teacher roles but also affects student achievements. Consequently, the issue of teacher job satisfaction needs to

\footnotetext{
*Corresponding author.
}

How to cite this paper: Noori, N., Fatemi, M.A. and Najjari, H. (2014) The Relationship between EFL Teachers' Motivation and Job Satisfaction in Mashhad Language Institutions. Open Access Library Journal, 1: e843. 
be studied very carefully from every viewpoint and attitude [3].

\subsection{Statement of the Problem}

In the discussions of motivation in SLA, special attention is often devoted on the language learner. Research on motivation reported during the last three decades in the field provides evidence for this. However, with the recent findings of a close relationship between teacher motivation and student motivation in many learning contexts [4], the phenomenon of teacher motivation also needs empirical investigations to discover the facts about the nature of this relationship in different language learning contexts.

In many educational contexts, teachers increasingly leave the profession after a few years in service. In addition studies worldwide have found that teachers are exposed to the highest level of job related stress and that they are less satisfied with their jobs than any other professional group. Research into teacher satisfaction has a great effect and value because job dissatisfaction causes little commitment and productivity, reduced ability to meet student needs, certain degrees of psychological disorders and high levels of stress related disability [5].

[6] suggested that language learner motivation is highly recommended both in educational and cultural context. With this claim, it is possible to assume that the difficulty in learning a language as well as learning other subjects poses more challenges to language teachers too. Language teachers, on the other hand to other subject teachers in homogeneous classes, frequently have to keep themselves informed of many different socio-cultural and affective factors which ascertain the success of the learners.

\subsection{Significance of the Study}

Due to the fact that there is not enough research on the relationship between EFL teacher job satisfaction and motivation, first and foremost, this study is set out to investigate how EFL teachers feel with their job, what motivates them, how they manage to sustain their motivation and remain in the teaching profession. According to [7], understanding the determinants of ESL teacher motivation in the country is significant for three reasons: it can improve student motivation; it can help to the country's language education reforms; and it can cause the satisfaction and accomplishment of teachers themselves.

\subsection{Definition of Key Terms}

\subsubsection{Teacher Motivation}

There are many motivation theories for explaining for just about everything that happens to people at work. Many definitions of motivation exist in the literature and numerous debates surround these definitions. This lack of clarity on how to define motivation quickly created problems for researches. Different perspectives arose on how to define motivation. As a way to deal with the confusion over the definitional and conceptual issues with motivation construct, researchers switched their way to facet specific motivation. Work settings have many of these specific motivations present at any given time. At the amount of practical application, understanding that teachers are motivated by the necessity to achieve ideal-oriented goal is of no real use. For practical purposes, much non specificity is needed and attention must be inclined to what, precisely, motivates rather than at why it motivates [8]. In schools, motivation among teachers is required for the objective of effective teaching learning process. Thus efficient teaching somewhat is the consequence of motivation [9]. Students' attitudes and behavior, the task of teaching affected teachers' motivation, commitment to teaching and respondents' attitudes towards various language institution based factors, towards their work and their relationship with students are interpreted in this research. Finally, a few studies of motivation have examined health related outcomes such as stress and psychological well-being. For instance, motivation has been linked to stress and psychological well-being [5].

\subsubsection{Teacher Job Satisfaction}

The underlying conceptual problem connected with researching job satisfaction is that there is no agreed definition of the term. A variety of definitions is evident, and the disparity amongst these relates both to the depths of analyses of the concept and to interpretation of it [8]. Job satisfaction is really a multidimensional and dynamic construct affected by many factors concerning individual characteristics, to options that come with the working context and to specific facets of the job [10]. In general job satisfaction equates with how someone feels about his job [11]. Based on [12], job satisfaction identifies "a state of mind encompassing all those feelings determined by the extent to which the individual perceives her/his job related needs to be being met” (p. 294). And 
similarly, teacher satisfaction "refers to a teacher's affective relation to his or her teaching role and is a function of the perceived relationship between what one wants from teaching and what one perceives it is offering to a teacher" ([13], p. 359).

Teacher motivation and job satisfaction will vary constructs but inextricably linked as one influences the other. In most cases, motivation describes to an innate stimulus for behavior and action, an internal drive which inspires us to behave in the light of a specific context, whereas job satisfaction identifies a product of a behavior or action in the light of a specific context [11].

Also two sets of factors appear to affect teachers' ability to perform effectively:

1) Work context factors referred to the teaching environment.

2) Work content factors referred to teaching ([14], p. 56).

1) Work Context Factors

These are factors extrinsic to the teacher. [14] defines it as follow:

They include working conditions such as class size, discipline conditions, and accessibility to teaching materials; the grade of the supervision; and basic psychological needs such as money, status and security.

When present, these factors prevent dissatisfaction. But these factors may not have a long motivational effect or result in improved teaching. A survey conducted by the National Center for Education Statistics found that teacher compensation, including salary, benefits, and supplemental income, showed little relation to long-term satisfaction with teaching as a career (p. 56).

\section{2) Work Content Factors}

Work content factors are intrinsic to the job itself. They include opportunities for professional development, recognition, challenging and varied work, increased responsibility, achievement, empowerment, and authority. Three major areas that connect with teachers' job satisfaction:

a) Feedback may be the factor most strongly linked to job satisfaction, yet teachers typically receive almost no accurate and helpful feedback regarding their teaching.

b) Autonomy is freedom to produce collegial relationships to perform tasks.

c) Collegiality is experiencing challenging and stimulating work, creating school improvement plans, and leading curriculum development groups ([14], p. 56).

\subsubsection{EFL Teachers}

In TESOL, those who teach English in non-native English countries (except UK, USA, Australia, New Zealand and Canada) are often categorized as EFL teachers. The term ESL is only used to introduce language teaching in native contexts [15].

\subsubsection{Language Institutions}

Language Institutions offer courses for all levels of language proficiency and all age groups. Some foreign languages are taught in these institutions. The institutions use up-to-date text-books and professional teachers holding MA or BA in TEFL or other fields. The demand for English in Iran has grown rapidly over the last two decades and language institutions have more important role than schools and universities.

\subsection{Limitations of the Study}

This study's focus was on teachers who teach in language institutions. It is possible that the result of it would not be applicable to schools or universities. And the current study was done in Iranian context; consequently, its results cannot be generalized to other contexts. The sample did not include teachers who move away from participating or who did not complete a greater portion of their questions. The study was also delimited to participants who were present in the classroom at the time of distribution of the questionnaires. Some teachers took questionnaire home and collected several later, therefore, there was no control the degree to which teachers collaborated or discussed the questions and influenced each other. In addition, faced specific approach used in this research. The faced specific approach has been almost subsumed under specific topical area rather than comprising an increasingly strong base for a broad job satisfaction and motivation in and of itself.

\subsection{Review of Literature}

Gibson, et al. (1989) commented that motivation and job satisfaction are connected but are not synonymous. 
They certified that job satisfaction is one area of the motivational process. While motivation is chiefly concerned with purposive behavior, job satisfaction assesses the performance developed by experiencing different job activities and helpful effects. It is possible that an employee may present low motivation from the organization's perspective yet enjoys every facets of the job. This state represents high job satisfaction (as cited in [16]). [16] also gave reasons that a highly motivated employee might also be dissatisfied with every facets of his or her job.

Research on teacher job satisfaction has identified a variety of factors that affect job satisfaction and teacher motivation. According to [17], these factors divided into two domains: intrinsic and extrinsic factors. Also extrinsic factors divided into two factors: school factors and system factors.

\subsubsection{Factors Intrinsic to Teaching}

Based on some studies such as [12] [17]-[21], it is concluded that the key factors found to subscribe to teacher job satisfaction relate with the specific work of teaching, that is, dealing with children, developing warm personal relationships with children, the intellectual challenge of teaching, autonomy and independence and having opportunities to experience new ideas.

Teachers, no matter of sex, teaching experience, position held and location and kind of school, have been found to acquire their greatest satisfaction and experience a great sense of success through dealing with and for young people and by enabling young people to understand their potential, experience success and grow into responsible adults. Teachers universally have already been found to value student enthusiasm and responsiveness as an important factor of their own enthusiasm while listing students' low motivation as a discourager. Quite simply, in the same way dealing with students and affecting their lives is probably the most central and powerful supply of satisfaction for teachers, dealing with difficult and demotivated students could have negative consequences for teacher satisfaction and could be the origin of emotionally exhausting and discouraging experiences.

\subsubsection{Factors Operating at the School Level}

The second supply of factors affecting job satisfaction include largely school based factors such as school leadership, school climate and participation in decision making, support from leadership and peers, school infrastructure, the school's relation using its local community, workload, staff supervision, class size, school communication networks [17]. These are factors extrinsic to the task of teaching but can become powerful dissatisfiers when absent or problematic. According to some studies such as [2] [17] [22] [23], the significance of a school culture with strong support networks that promotes collaboration, communication, collegiality has been identified by many studies as a central determinant of teacher job satisfaction.

\subsubsection{Factors Operating at the System Level}

The third supply of factors includes those coming from the wider social context, the state government and the system. They are factors which are extrinsic to the job itself and include imposed educational change, increased expectations on schools to cope with and solve social problems, community's opinion of teachers, the image of teachers portrayed in the media, level of support by the system to implement curricular changes, support services to teachers, promotion prospects, status of teachers, conditions of service, salary [5]. Based on [13], Teachers generally regard job dissatisfaction as mainly originating from work overload, poor pay and perceptions of how teachers are regarded by society. To [5], these extrinsic, systemically based factors have been found as powerful dissatisfiers which detract from or prevent from the core business of teaching and which can meaningfully affect teachers' motivation and their wish to stay in teaching.

\subsubsection{Teacher Job Satisfaction and Teacher Efficacy}

[18] stated that another important construct in the study of teacher job satisfaction which affects how teachers deal with and manage sources of job dissatisfaction is the concept of teacher efficacy. Teacher efficacy refers to the self-perception of teaching competence; it is the self-belief of teachers that they can affect positive effect on their students' growth and success. Teachers with a high sense of efficacy have been found to show greater eagerness for and commitment to teaching, display greater willingness to deal with students' emotional and behavioral difficulties, show greater need and readiness to carry out and find better ways of teaching and generally exhibit higher levels of job satisfaction. A good reason for the importance of teacher efficacy and its relation to job satisfaction is provided by [2] who stated: 
Teacher efficacy has at least two important motivational outcomes: Firstly it influences the kind of challenges and environments teachers are prepared to face in their work. If teachers believe that teaching difficult subject matter or working with colleagues is so bad to deal with it (low self-efficacy) they will refuse these situations on the side of less challenging and finally less beneficial learning contexts. Secondly, strong self-efficacy beliefs influence effort and persistence. Teachers with high self-efficacy quickly recover after something unpleasant setbacks in their teaching efforts and this fast recovering is vital in helping students to keep their diligence and self-belief (p. 3).

Based on some studies such as [12] [17]-[21], it is concluded that the key factors found to subscribe to teacher job satisfaction relate with the specific work of teaching, that is, dealing with children, developing warm personal relationships with children, the intellectual challenge of teaching, autonomy and independence and having opportunities to experience new ideas. According to some studies such as [2] [17] [22] [23], the significance of a school culture with strong support networks that promotes collaboration, communication, collegiality has been identified by many studies as a central determinant of teacher job satisfaction. [21] stated teachers generally regard job dissatisfaction as mainly originating from work overload, poor pay and perceptions of how teachers are regarded by society.

\subsection{Research Question and Hypothesis}

Based on the above mentioned issues, to our knowledge, this study posed the following research question:

Q1: Is there any relationship between EFL teachers' motivation and their job satisfaction in Mashhad language institutions?

$\mathbf{H o}_{1}$ : There is no significant relationship between EFL teachers' motivation and their job satisfaction in Mashhad language institutions.

\section{Method}

\subsection{Participants and Settings}

The sample for this study included 250 teachers selected by random sampling technique from among 14 language institutions in the North-east of Iran, Mashhad (fall 2012). The sample consisted of teachers with varying age (63\% from 22 to 30, 37\% from 31 to 40 ), gender ( $53 \%$ female, $47 \%$ male), work experience ( $45 \%$ from 6 to 10 years of experience, $25 \%$ from 1 to 5 years of experience, $26 \%$ from 11 to 15 years of experience and $5 \%$ more than 16 years of experience), level of education (34\% a Master's degree, 61\% Bachelor's degree and 5\% lower than BA), and field of education (71\% English majors and 29\% studied in other fields). The following tables showed the characteristics of the survey participants.

\subsection{Procedure}

In order to recognize EFL teachers' motivation and job satisfaction, the researcher administered the piloted questionnaires (TMQ and TJSQ) in paper and pencil formats randomly to 320 EFL teachers who taught language skills courses in different levels in different Mashhad language institutions. Prior to data collection, letters were dispatched to the principals of selected language institutions, explaining the significance of the study, and requesting that they allow their teachers to participate. Prior to the day of distribution of questionnaires, participants were alerted of the meaning and need for the study. The participants took the questionnaires home, filled them in and submitted them to the researcher over the following weeks. Reservations were made for a second day to collect data from participants who could not be present on the first day. A total of 320 questionnaires were distributed, 50 were not returned, 20 were incomplete. The total number of acceptable data from teachers therefore was 250 . To receive reliable data, the researchers explained the purpose of the study to the participants, and assured them that their information would be confidential.

The quantitative data for the current study included EFL teachers' responses to the close-ended questions on the teacher motivation questionnaire (TMQ) and job satisfaction questionnaire (TJSQ). These responses were entered into a data file and analyzed statistically using the computer software program Statistical Package for Social Sciences. Statistical analyses carried out on the data included Pearson product-moment correlation coefficient and Cronbach's alpha coefficient. 


\subsection{Instrumentations}

The questionnaires that administered in this study were taken from an article which conducted a research about EFL teacher motivation and job satisfaction in Greek. Based on a conceptual framework (factors operating at the school based level, factors relating to wider domain of society, school culture, students attitudes and behavior, the task of teaching affected teachers' motivation, commitment to teaching and the concept of self-efficacy), [5] developed these questionnaires in Greece.

\subsubsection{Teacher Job Satisfaction Questionnaire (TJSQ)}

This part of the questionnaire asked respondent questions related to their level of satisfaction with various aspects extrinsic to the task of teaching such as their recognition by students, peers, parents and the wider community, the image of teachers, their status in society, their salary, working hours, benefits etc. The questions in this part were measured on a 5 point scale ranging from $1=$ highly satisfying to $5=$ highly dissatisfying. The Cronbach's alpha coefficient of this questionnaire was $0.72(r=0.72)$.

\subsubsection{Teacher Motivation Questionnaire (TMQ)}

This part of the questionnaire elicited respondents' attitudes towards various language institution based factors, towards their work and their relationship with students. The questions in this part were measured on a 5 point scale ranging from $1=$ strongly agree to $5=$ strongly disagree. The Cronbach's alpha coefficient of this questionnaire was $0.71(r=0.71)$.

\subsection{Design Issues}

Finally, there are issues related to the design of job satisfaction and motivation studies, such as the means by which motivation and job satisfaction data are collected. The predominate methodology used in job satisfaction and motivation research is the use of surveys. This methodology has several limitations regarding its use. First, this type of design is susceptible to same source bias that can artificially inflate relationships. One way around this is to use a split-sample approach where groups are split into subgroups whose responses can be used to separately measure variables in a relationship (e.g., [24]).

\section{Results and Discussions}

Having collected the required data based on the mentioned data collection instruments and procedures, the researchers conducted data analysis and tested the hypothesis formulated for the present study.

\subsection{Descriptive Statistics of TJSQ Questions}

This questionnaire investigated teachers' degree of satisfaction with various factors extrinsic to the task of teaching-namely language institution based factors and especially system based factors (factors of the wider social domain). Questions of this teacher job satisfaction questionnaire were divided into three sections: factors that respondents were satisfied with and factors that are dissatisfied with and factors that were ambivalent. There searcher used 1 for highly satisfaction, 2 for satisfaction, 3 neither satisfying nor dissatisfying and 4 for dissatisfying. Therefore, the less Mean showed the more satisfaction.

\subsubsection{Satisfied Extrinsic Factors}

Results were presented in descending order, starting from those factors the respondents seemed to be most satisfied with and proceeding to factors they seemed less satisfied or dissatisfied with. The majority of EFL teachers (see Table 1) in the institutions seemed to be most satisfied with their status as an EFL teacher in their language institution $(87.6 \%)$ and $(\mathrm{M}=1.9440$ and $\mathrm{SD}=0.54961)$, the amount of recognition they received for their efforts from their students $(83.6 \%)$ and $(\mathrm{M}=2.0960$ and $\mathrm{SD}=0.68165)$, their status as an EFL teacher in society $(55.2 \%)$ and $(M=2.2520$ and $S D=0.90763)$, the amount of recognition they received for their efforts from parents and community $(48.8 \%)$ and $(\mathrm{M}=2.3320$ and $\mathrm{SD}=0.76427)$, the amount of recognition they received for their efforts from people in their language institution $(70.4 \%)$ and $(\mathrm{M}=2.3560$ and $\mathrm{SD}=0.77955)$. A significant number of teachers also felt satisfied with their amount of recognition they received for their efforts from their employer/institution governing body $(65.2 \%)$ and $(M=2.4160$ and $S D=0.91996)$, their opportunities for 
Table 1. Descriptive statistics of teachers’ answers to questions related to job satisfaction.

\begin{tabular}{ccccccc}
\hline Questions & HS & S & NS & D & Mean & SD \\
\hline Q6 & 18.0 & 69.6 & 12.4 & & 1.9440 & 0.54961 \\
Q4 & 12.8 & 70.8 & 10.4 & 6.0 & 2.0960 & 0.68165 \\
Q5 & 25.6 & 29.6 & 38.8 & 6.0 & 2.2520 & 0.90763 \\
Q3 & 18.0 & 30.8 & 51.2 & & 2.3320 & 0.76427 \\
Q1 & 6.4 & 64.0 & 17.2 & 12.4 & 2.3560 & 0.77955 \\
Q2 & 11.6 & 53.6 & 16.4 & 18.4 & 2.4160 & 0.91996 \\
Q12 & 12.8 & 44.8 & 24.0 & 17.6 & 2.7560 & 0.64837 \\
Q13 & 6.4 & 34.0 & 37.2 & 22.4 & 2.7840 & 0.87380 \\
\hline
\end{tabular}

Note: $\mathrm{HS}=$ highly satisfying $=1 ; \mathrm{S}=$ satisfying $=2 ; \mathrm{NS}=$ neither satisfying nor dissatisfying $=3$ and $\mathrm{D}=$ dissatisfying $=4$.

promotion or advancement (57.6\%) and $(\mathrm{M}=2.7560$ and $\mathrm{SD}=0.64837)$ and the physical working environment of their language institution (infrastructure, resources etc.) $(40.4 \%)$ and $(\mathrm{M}=2.7840$ and $\mathrm{SD}=0.87380)$.

\subsubsection{Dissatisfied Extrinsic Factors}

As far as sources of dissatisfaction were concerned (see Table 2), the majority of respondents seemed dissatisfied with system based factors such as the government's initiatives for improving the status of EFL teachers (69.6\%) $(\mathrm{M}=3.6280$ and $\mathrm{SD}=0.60918)$ and over $1 / 3$ of the teachers were dissatisfied with the range of professional in-services $(36.0 \%)(\mathrm{M}=3.0760$ and $\mathrm{SD}=0.80049)$. Many of the teachers felt dissatisfied with the infrastructure and resources of their working environment and opportunities for their professional development offered by the government.

\subsubsection{Ambivalent System Based Factors}

Teachers felt there was room for improvement in some factors (see Table 3). The results of teacher official working hours were $(M=2.8000$ and $S D=1.04900)$. Participants were divided on this issue: slightly over $1 / 3$ of the teachers felt dissatisfied with their official working hours (34.0\%), slightly under $1 / 4$ of the teachers felt there was room for improvement (24.8\%), slightly over $1 / 4$ felt satisfied (28.4\%) and (12.8\%) of the teachers felt strongly satisfied. The next factor that elicited the following result was benefits such as holidays, educational leaves $(M=2.9160$ and $S D=0.05108)$ was a source of dissatisfaction of $1 / 3$ of the respondents $(34.8 \%)$ and more than $1 / 4$ of the respondents (28.4\%) felt that there was room for improvement and the rest of the respondents were satisfied. The other factor was public perception of EFL teachers and how they were portrayed in the media $(M=2.9240$ and $S D=0.72687)$. Slightly under $1 / 2$ of the respondents $(46.8 \%)$ expressed a neutral attitude feeling neither satisfied nor dissatisfied. The other factor was salary $(M=2.9680$ and $S D=0.85903)$. Participants were divided on this issue: slightly under $1 / 2$ of the teachers felt there was room for improvement (45.6\%) and $28.8 \%$ of the teachers felt dissatisfied and $19.2 \%$ felt satisfied and only $6.4 \%$ felt highly satisfying. The final factor was the way that professional associations work the improvement of the ELT profession $(\mathrm{M}=$ 3.2000 and SD $=0.71135$ ). Slightly under $1 / 2$ of the respondents $(45.6 \%)$ expressed a neutral attitude feeling neither satisfied nor dissatisfied.

\subsection{Descriptive Statistics of TMQ Questions}

The second part of the questionnaire investigated teachers' attitudes towards various language institution based factors such as language institution leadership, language institution climate, support from leadership and peers, language institution communication networks. These were factors extrinsic to the task of teaching but can become powerful dissatisfiers when absent or problematic. In addition, this part of the questionnaire also included statements relating to factors intrinsic to the task of teaching such as the quality of teacher student relationship, teachers' sense of efficacy and teachers' feelings regarding their work such as challenge of teaching and commitment to teaching which act as powerful sources of motivation for teachers. The researcher used 1 for strongly 
Table 2. Descriptive statistics of teachers' answers to questions of job satisfaction.

\begin{tabular}{ccccccc}
\hline Questions & HS & S & NS & D & Mean & SD \\
\hline Q10 & & 28.4 & 35.6 & 36.0 & 3.0760 & 0.80049 \\
Q9 & 6.8 & 23.6 & 69.6 & 3.6280 & 0.60918 \\
\hline
\end{tabular}

Note: $\mathrm{HS}=$ highly satisfying $=1 ; \mathrm{S}=$ satisfying $=2 ; \mathrm{NS}=$ neither satisfying nor dissatisfying $=3$ and $\mathrm{D}=$ dissatisfying $=4$.

Table 3. Descriptive statistics of teachers' answers to questions of job satisfaction.

\begin{tabular}{ccccccc}
\hline Questions & HS & S & NS & D & Mean & SD \\
\hline Q15 & 12.8 & 28.4 & 24.8 & 34.0 & 2.8000 & 1.04900 \\
Q14 & 6.4 & 30.4 & 28.4 & 34.8 & 2.9160 & 0.05108 \\
Q7 & & 30.4 & 46.8 & 22.8 & 2.9240 & 0.72687 \\
Q11 & 6.4 & 19.2 & 45.6 & 28.8 & 2.9680 & 0.85903 \\
Q8 & & 17.2 & 45.6 & 37.2 & 3.2000 & 0.71135 \\
\hline
\end{tabular}

Note: $\mathrm{HS}=$ highly satisfying $=1 ; \mathrm{S}=$ satisfying $=2 ; \mathrm{NS}=$ neither satisfying nor dissatisfying $=3$ and $\mathrm{D}=\operatorname{dissatisfying}=4$.

agree, 2 for agree, 3 don’t know and 4 for disagree. Therefore, the less Mean showed the more agree.

\subsubsection{Teachers' Attitudes towards Language Institution Based Factors}

According to Table 4, most of teachers felt satisfied with the opportunities and support from language institution administration for trying out new ideas and practices $(\mathrm{M}=3.7440$ and $\mathrm{SD}=0.56546)(80.8 \%$ of the teachers) and (12.8\%) of the teachers answered that they didn't know. (6.4\%) of the teachers agreed that Language institution administration did not support them. Over $1 / 2$ of teachers valued Cooperation with colleagues $(\mathrm{M}=$ 2.3840 and $\mathrm{SD}=0.78422)(62.4 \%), 12.8 \%$ of teachers disagreed with, and $18.8 \%$ of teachers answered that they didn't know. $18.8 \%$ of the participants disagreed that their institution provided a collegial supportive environment for them to work in $(\mathrm{M}=2.5520$ and $\mathrm{SD}=0.93959)$. Less than $1 / 3(30.4 \%)$ of the participants answered they didn't know. 38.0\% of the participants agreed that their institution provided a collegial supportive environment for them to work in and $12.8 \%$ strongly agreed that their institution provided a collegial supportive environment for them to work in. Slightly under half of the participants agreed that their work load $(\mathrm{M}=2.6800$ and SD $=0.96609$ ) was heavy $(48.4 \%) .6 .4 \%$ felt high pressure, $16.0 \%$ of the participants answered they didn't know and $29.2 \%$ of the participants disagreed that their work load was heavy. $40.4 \%$ of teachers agreed that extra-curricular activities $(\mathrm{M}=2.7840$ and $\mathrm{SD}=0.73996)$ were as stimulating to them as teaching is, $40.8 \%$ of teachers didn't know and $18.8 \%$ of the teachers disagreed. $56.8 \%$ of the participants disagreed that administrative meetings in language institution ( $\mathrm{M}=3.2600$ and $\mathrm{SD}=0.96962)$ were not helpful in solving teachers' problems. $18.8 \%$ of the participants answered that they didn't know. $18.0 \%$ of participants agreed that administrative meetings in institution were not helpful in solving teachers' problems.

Two statements in this part of the questionnaire in addition were related to teachers' confidence in their ability to use a positive effect on their students' progress and success. Teachers' sense of efficacy was an effective motivational factor because assists teachers' achievement and perseverance in spite of obstacles and problems to investigate and better the quality of their teaching [5]. There were two questions (see Table 5) about self-efficacy $(\mathrm{M}=2.3120$ and $\mathrm{SD}=0.83313)$ and $(\mathrm{M}=2.2360$ and $\mathrm{SD}=0.93370) .11 .6 \%$ of the teachers strongly agreed and $58.0 \%$ agreed that they had dealt effectively with the problems of their students. $22.8 \%$ of the teachers strongly agreed and $42.4 \%$ of the teachers agreed that they had positively influenced students' lives through their teaching. It meant that Iranian EFL teachers had a very good self-efficacy.

\subsubsection{Teachers' Attitudes towards Factors Intrinsic to Teaching}

A look at Table 6 revealed that less than half (41.2\%) of the EFL teachers regretted their career choice $(\mathrm{M}=$ 2.8840 and SD $=1.08963)$. Less than half $(46.8 \%)$ of the participants felt the relationship with their students as the most rewarding aspect of their work $(\mathrm{M}=2.7080$ and $\mathrm{SD}=0.90444)$. The negative points about teaching 
Table 4. Descriptive statistics of teachers' attitudes towards language institution based factors.

\begin{tabular}{ccccccc}
\hline Questions & SA & A & N & D & Mean & SD \\
\hline Q3 & 6.0 & 62.4 & 18.8 & 12.8 & 2.3840 & 0.78422 \\
Q18 & 12.8 & 38.0 & 30.4 & 18.8 & 2.5520 & 0.93959 \\
Q11 & 6.4 & 48.4 & 16.0 & 29.2 & 2.6800 & 0.96609 \\
Q6 & & 40.4 & 40.8 & 18.8 & 2.7840 & 0.73996 \\
Q8 & 6.4 & 18.0 & 18.8 & 56.8 & 3.2600 & 0.96962 \\
Q1 & & 6.4 & 12.8 & 80.8 & 3.7440 & 0.56546 \\
\hline
\end{tabular}

Note: $\mathrm{SA}=$ strongly agree $=1 ; \mathrm{A}=$ agree $=2 ; \mathrm{N}=$ don't know $=3$ and $\mathrm{D}=$ disagree $=4$.

Table 5. Descriptive statistics of teachers’ perceptions of their teaching efficacy.

\begin{tabular}{ccccccc}
\hline Questions & SA & A & N & D & Mean & SD \\
\hline Q13 & 11.6 & 58.0 & 18.0 & 12.4 & 2.3120 & 0.83513 \\
Q15 & 22.8 & 42.4 & 23.2 & 11.6 & 2.2360 & 0.93370 \\
\hline
\end{tabular}

Note: $\mathrm{SA}=$ strongly agree $=1 ; \mathrm{A}=$ agree $=2 ; \mathrm{N}=$ don't know $=3$ and $\mathrm{D}=$ disagree $=4$.

Table 6. Descriptive statistics of teachers' attitudes towards their work.

\begin{tabular}{|c|c|c|c|c|c|c|}
\hline Questions & SA & A & $\mathrm{N}$ & D & Mean & $\mathrm{SD}$ \\
\hline Q2 & 12.8 & 27.2 & 18.8 & 41.2 & 2.8840 & 1.08963 \\
\hline Q4 & 6.4 & 40.4 & 29.2 & 24.0 & 2.7080 & 0.90444 \\
\hline Q5 & & 16.8 & 22.0 & 61.2 & 3.4440 & 0.76499 \\
\hline Q7 & & 17.6 & 42.0 & 40.4 & 3.2280 & 0.72810 \\
\hline Q9 & 24.4 & 39.6 & 24.4 & 11.6 & 2.2320 & 0.94962 \\
\hline Q10 & 24.8 & 51.6 & 11.2 & 12.4 & 2.1120 & 0.92024 \\
\hline Q14 & 12.8 & 5.2 & 27.6 & 54.4 & 3.2360 & 1.02788 \\
\hline Q16 & & 18.4 & 22.8 & 58.8 & 3.4040 & 0.78181 \\
\hline Q19 & 18.0 & 52.4 & & 29.6 & 2.4120 & 1.09501 \\
\hline
\end{tabular}

Note: $\mathrm{SA}=$ strongly agree $=1 ; \mathrm{A}=$ agree $=2 ; \mathrm{N}=$ don't know $=3$ and $\mathrm{D}=$ disagree $=4$.

were not alarming. Only $16.8 \%$ of the teachers felt emotionally drained from their work $(\mathrm{M}=3.4440$ and $\mathrm{SD}=$ 0.76499). Only $17.6 \%$ of the participants agreed that they could not see themselves continuing to teach for the rest of their career $(\mathrm{M}=3.2280$ and $\mathrm{SD}=0.72810)$ and $42.0 \%$ of the participants expressed that there was room for improvement. The majority of the participants expressed total commitment to teaching $(\mathrm{M}=2.2320$ and $\mathrm{SD}=$ 0.94962) (64.0\%). The majority of the participants found that teaching increased their self-esteem ( $\mathrm{M}=2.1120$ and SD $=0.92024)(76.4 \%)$. More than half of the teachers (54.4\%) disagreed that teaching often stressed them $(\mathrm{M}=3.2360$ and $\mathrm{SD}=1.02788)$. More than half $(58.8 \%)$ of the participants disagreed that they had felt burn out from their work $(\mathrm{M}=3.4040$ and $\mathrm{SD}=0.78181)$. The majority of the participants found teaching mentally stimulating $(\mathrm{M}=2.4120$ and $\mathrm{SD}=1.09501)(70.0 \%)$.

Table 7 showed that for the majority of teachers, their learners' ensuing discipline problems $(\mathrm{M}=2.3080$ and $\mathrm{SD}=1.01254)$, lack of motivation for learning English $(\mathrm{M}=2.8520$ and $\mathrm{SD}=1.03653)$ and attitude problems $(\mathrm{M}=2.4640$ and $\mathrm{SD}=1.03779)$ significantly impaired their motivation for teaching and had an impact on the quality of their teaching.

Research question 1: Is there any relationship between EFL teachers' motivation and the levels of job satisfaction in Mashhad language institutions?

Table 8 showed the relationship between teacher motivation (as measured by TMQ) and job satisfaction (as 
Table 7. Descriptive statistics of teachers’ attitudes towards students.

\begin{tabular}{ccccccc}
\hline Questions & $\mathrm{SA}$ & $\mathrm{A}$ & $\mathrm{N}$ & $\mathrm{D}$ & Mean & SD \\
\hline Q12 & 22.8 & 41.2 & 18.4 & 17.6 & 2.3080 & 1.01254 \\
Q17 & 12.8 & 23.6 & 29.2 & 34.4 & 2.8520 & 1.03653 \\
Q20 & 18.0 & 40.8 & 18.0 & 23.2 & 2.4640 & 1.03779 \\
\hline
\end{tabular}

Note: $\mathrm{SA}=$ strongly agree $=1 ; \mathrm{A}=$ agree $=2 ; \mathrm{N}=$ don't know $=3$ and $\mathrm{D}=$ disagree $=4$.

Table 8. Pearson correlation of teacher motivation and job satisfaction.

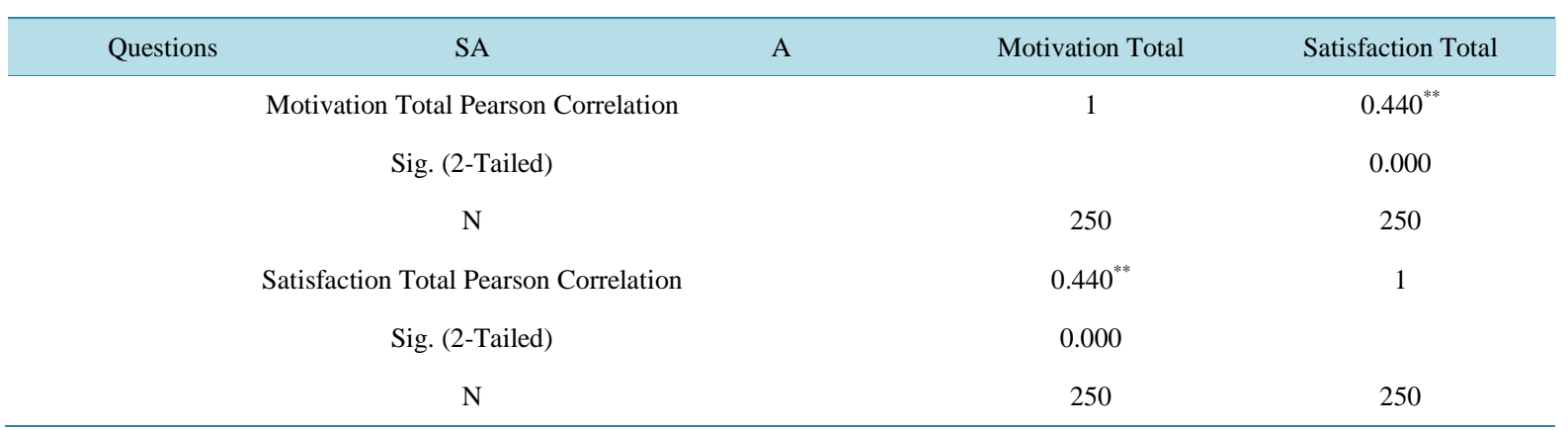

Note: ${ }^{* *}$ Correlation is significant at the 0.01 level (2-tailed).

measured by TJSQ). The Pearson product-moment correlation coefficient was used. The result indicated that there was a significant moderate relationship between the two variables. Thus, the null-hypothesis, that there is no significant relationship between EFL teachers' motivation and the levels of job satisfaction in language institutions was rejected. As the results of Table 8 revealed, there was positive moderate relationship $(r=0.44, p<$ 0.01) between EFL teachers' motivation and the levels of job satisfaction in Mashhad language institutions. A positive correlation indicated that higher values on the job satisfaction were associated with higher values of teacher motivation.

\section{Conclusions}

The results of TMQ and TJSQ approved that there was a significant positive correlation between teacher motivation and job satisfaction. This result was in line with [5]. This study reinforces the theory that the needs satisfaction or work related needs of employees, if considering national background as not being important, can be grouped based on need theories of motivation [1].

The results of this study coincided with results from international research on teachers' job satisfaction [5] [17] [20] [25] where the most strongly felt dissatisfiers were facts extrinsic to the task of teaching such as the range of professional in services courses/programs/support offered to EFL teachers and the way that governments work for the betterment of their status, and mostly out of control of teachers and language institutions found within the domain of the state government and the system.

The difference of this study with previous studies about job satisfaction and teacher motivation was the context of the study. The previous researches' context was school but in this study, the context was language institution. These institutions were private and had no connection with the government and maybe this was why they were dissatisfied with the systems factors. The other difference of this study with previous (as [5]) was the degree satisfaction of teachers about benefits and official working hours. The result of previous studies showed that teachers were satisfied with their benefits and official working hours but in this study teachers were neither satisfied nor dissatisfied. Also nearly half of the teachers reported their work load was heavy.

The majority of EFL teachers expressed total commitment to teaching and found that teaching increased their self-esteem they also found teaching mentally stimulating. These results were in line with studies such as [5] [18]. Less than half of the participants felt the relationship with their students as the most rewarding aspect of their work, this result differed from [5] [12] [17]-[21]. The percentages of questions about teacher stress, feeling burn out and emotionally drained from teaching were not alarming in this research. These findings differed from 
the results of international research that teachers reported the highest levels of stress and burn out than any professional group ([2] [5] [26] [27]).

A possible explanation for the rather low levels of stress and burn out expressed by EFL teachers in this research may be found in their students. One of the powerful demotivating factors for teachers was students' lack of motivation or lack of interest in the subject. Most of the Iranian students who go to language institutions like learning English, because the methods of teaching English in language institutions is different from schools. Like pervious researches (such as [5]), EFL teachers reported that students' discipline problems and attitudes problems significantly reduced their own motivation and enthusiasm for teaching and had an impact on the quality of their teaching.

One important point in this research was that in spite of teachers' positive attitudes towards their intrinsic aspects of their work, many teachers regretted to have chosen teaching. This result went against previous researches that most of the teachers had no regret for entering the teaching profession (such as [5]). Some teachers felt sorry about entering teaching profession, although they felt satisfied or strongly satisfied with their salary. It seemed that it wasn't related to salary.

Two other important issues were salary and position in the language institution. Most of teachers who were satisfied with their salary had important position in the language institutions. It seemed that there was a direct relationship between salary and position. This result was in line with [27], they stated that those teachers who hold different promotion positions were found to differ on some measures of satisfaction.

In sum, teacher motivation and job satisfaction of EFL teachers was good. They had high efficacy and commitment, they didn't experience much stress and they were relatively satisfied with the language institution based factors.

\section{Acknowledgements}

I greatly appreciate the teachers who participated in this study. They provided me with so much precious data and perhaps contributed the most to this research.

\section{References}

[1] Ololube, N.P. (2006) Teachers Job Satisfaction and Motivation for School Effectiveness: An Assessment. ERIC Number: ED496539, 19 p.

[2] Morgan, M., Kitching, K. and O’Leary, M. (2007) The Psychic Rewards of Teaching: Examining Global, National and Local Influences on Teacher Motivation. AERA Annual Meeting, Chicago, April 2007, 19 p.

[3] Darmody, M. and Smyth, E. (2010) Job Satisfaction and Occupational Stress among Primary School Teachers and School Principals in Ireland. ESRI/The Teaching Council, Dublin,

[4] Bernaus, M., Wilson, A. and Gardner, R.C. (2009) Teachers’ Motivation, Classroom Strategy Use, Students’ Motivation and Second Language Achievement. Porta Linguarum, 12, 25-36.

[5] Karavas, E. (2010) How Satisfied Are Greek EFL Teachers with Their Work? Investigating the Motivation and Job Satisfaction Levels of Greek EFL Teachers. Porta Linguarum, 14, 59-78.

[6] Gardner, R.C. (2007) Motivation and Second Language Acquisition. Porta Linguarum, 8, 9-20.

[7] Jesus, S.N. and Lens, W. (2005) An Integrated Model for the Study of Teacher Motivation. Applied Psychology: An International Review, 54, 119-134. http://dx.doi.org/10.1111/j.1464-0597.2005.00199.x

[8] Evans, L. (1998) Teacher Morale, Job Satisfaction and Motivation.

[9] Khan, T. (2005) Teacher Job Satisfaction and Incentives: A Case Study of Pakistan: DFID, London. http://books.google.com

[10] Koustelios, A., Kouli, O. and Theodorakis, N. (2003) Job Security and Job Satisfaction among Greek Fitness Instructors. Perceptual Motor Skills, 97, 192-194. http://dx.doi.org/10.2466/pms.2003.97.1.192

[11] Scott, C., Stone, B. and Dinham, S. (2001) I Love Teaching but.... International Patterns of Teacher Discontent. Education Policy Analysis Archives, 9, 1-7.

[12] Evans, L. (2001) Delving Deeper into Morale, Job Satisfaction and Motivation among Education Professionals. Educational Management Administration \& Leadership, 29, 291-306. http://dx.doi.org/10.1177/0263211X010293004

[13] Zembylas, M. and Papanastasiou, E. (2004) Job Satisfaction among School Teachers in Cyprus. Journal of Educational Administration, 42, 357-374. http://dx.doi.org/10.1108/09578230410534676 
[14] National Center for Education Statistics (1997) Job Satisfaction among America's Teachers: Effects of Workplace Conditions, Background Characteristics, and Teacher Compensation. Office of Educational Research and Improvement, US Department of Education, Washington DC.

[15] Brown, H.D. (2007) Principles of Language Learning and Teaching. Pearson Education, New York.

[16] Peretomode, V.F. (1991) Educational Administration: Applied Concepts and Theoretical Perspective. Joja Educational Research and Publishers, Lagos.

[17] Dinham, S. and Scott, C. (1998) A Three Domain Model of Teacher and School Executive Career Satisfaction. Journal of Educational Administration, 36, 362-378.

[18] Day, C., Stobart, G., Sammon, P. and Kington, A. (2006) Variations in the Work and Lives of Teachers: Relative and Relational Effectiveness. Teachers and Teaching: Theory and Practice, 12, 169-192.

[19] Van Houtte, M. (2006) Tracking and Teacher Satisfaction: Role of Study Culture and Trust. The Journal of Educational Research, 99, 247-256. http://dx.doi.org/10.3200/JOER.99.4.247-256

[20] Scott, C. and Dinham, S. (2003) The Development of Scales to Measure Teacher and School Executive Occupational Satisfaction. Journal of Educational Administration, 41, 74-86. http://dx.doi.org/10.1108/09578230310457448

[21] Kyriacou, C. and Coulthard, M. (2000) Undergraduates' Views of Teaching as a Career Choice. Journal of Education for Teaching, 26, 117-126. http://dx.doi.org/10.1080/02607470050127036

[22] Papanastasiou, E.C. and Zembylas, M. (2005) Job Satisfaction Variance among Public and Private Kindergarten School Teachers in Cyprus. International Journal of Educational Research, 43, 147-167. http://dx.doi.org/10.1016/j.ijer.2006.06.009

[23] Woods, A.M. and Weasmer, J. (2004) Teacher Persistence; Job Satisfaction; Mentors; Leadership; Collegiality. Education, 123, 681-688.

[24] Ostroff, C., Kinicki, A. and Clark, M. (2002) Substantive and Operational Issues of Response Bias across Levels of Analysis: An Example of Climate-Satisfaction Relationships. Journal of Applied Psychology, 87, 355-368. http://dx.doi.org/10.1037/0021-9010.87.2.355

[25] Crossman, A. and Harris, P. (2006) Job Satisfaction of Secondary School Teachers. Educational Management Administration and Leadership, 34, 29-46. http://dx.doi.org/10.1177/1741143206059538

[26] Miller, G.V. and Travers, C.J. (2005) Ethnicity and the Experience of Work: Job Stress and Satisfaction of Minority Ethnic Teachers in the UK. International Review of Psychiatry, 17, 317-327. http://dx.doi.org/10.1080/09540260500238470

[27] Scott, C., Cox, S. and Dinham, S.K. (1999) The Occupational Motivation, Satisfaction and Health of English School Teachers. Educational Psychology, 19, 287-308. http://dx.doi.org/10.1080/0144341990190304 


\section{Appendix A}

\section{Teacher Job Satisfaction Questionnaire}

Background Information
A. Age 22 - $30 \quad 31-40 \quad 41-50 \quad 50+$
B. Gender Male Female
C. Total number of years service in teaching
1 - 5 years $6-10$ years $11-15$ years 16 years or more
D. Where did you teach in the past? Please tick more than once if necessary. Please write number of years service.

Public schools

Private schools

Language Institutions

Universities

Where do you currently teach? Please tick more than once if necessary.

Please write of years service

Public schools

Private schools

Language Institutions

Universities

1. In which fields did you study?

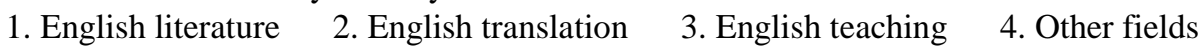

1. What is your level of education?

$\begin{array}{llll}\text { 1. Lower than } \mathrm{BA} / \mathrm{BSc} & \text { 2. BA/BSc } & \text { 3. } \mathrm{MA} / \mathrm{MSc} & \text { 4. } \mathrm{PhD}\end{array}$

Please tick your degree of satisfaction with each of the statements below.

How satisfying do you find:

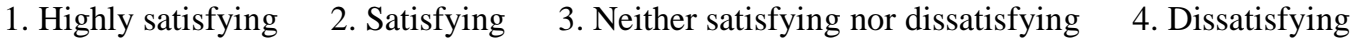
1. The amount of recognition you receive for your efforts from people in your Language institution.
2. The amount of recognition you receive for your efforts from your employer/language institution governing body.

3.The amount of recognition you receive for your efforts from parents and your community.

4. The amount of recognition you receive for your efforts from your students.

5. Your status as an EFL teacher in society.

6. Your status as an EFL teacher in your language institution.

7. The image of EFL teachers as portrayed in the media.

8. The way that educational professional associations work for the betterment of your profession.

9. The way that governments work for the betterment of your status.

10. The range of professional in-services courses/programs/support offered to EFL teachers

11. Your salary.

12. Your opportunities for promotion or advancement

13. The physical working environment of your language institution (infrastructure, resources etc.).

14. Your benefits (holidays, educational leaves etc.).

15. Your official working hours (in terms of quantity).

\section{Appendix B}

\section{Teacher Motivation Questionnaire}

Below is a series of statements relating to factors which have been found to affect teacher motivation. Please read each statement and tick your degree of agreement or disagreement with each one.
1. Strongly agree $\quad 2$. Agree $\quad 3$. Don't know $\quad$ 4. Disagree

1. Language institution administration does not support my efforts to try out new ideas/practices with my students.

2. If I had to do it again, I would still choose to become a teacher. 
3. Cooperation with colleagues in my language institution is rewarding and beneficial.

4. I feel that working closely with young people is the most fascinating aspect of my work.

5. I feel emotionally drained from my work.

6. Extra-curricular activities (language institution projects, organizing language institution events etc.) are as stimulating to me as teaching is.

7. I cannot see myself continuing to teach for the rest of my career.

8. Administrative meetings in language institution are not helpful in solving teachers' problems.

9. I feel total commitment to teaching.

10. Teaching increases my self-esteem.

11. I feel my workload (teaching and administrative work) is too heavy.

12. Students' discipline problems affect my motivation and enthusiasm for teaching.

13. I have dealt effectively with the problems of my students.

14. Teaching often stresses me.

15. I have positively influenced students' lives through my teaching.

16. I have felt burned out from my work.

17. My students' low motivation levels for learning English create great stress to me.

18. My language institution provides a collegial supportive environment for me to work in.

19. I find my work mentally stimulating.

20. Students' attitude problems (misbehavior in class, lack of interest in the subject etc.) have an effect on the quality of my teaching. 